\title{
Analisis Miskonsepsi Matematika Siswa Ditinjau dari Gaya Kognitif Field Independent
}

\author{
Indriwati $^{1{ }^{1}}$, Aska Muta Yuliani ${ }^{1)}$, Rina Susilowati ${ }^{1{ }^{1 *}}$ \\ ${ }^{1)}$ STKIP Paracendekia NW Sumbawa \\ *rinasusilowati7@gmail.com
}

Abstrak: Penelitian ini bertujuan untuk mengetahui miskonsepsi matematika siswa bedasarkan gaya kognitif field independent. Penentuan siswa pada penelitian ini menggunakan metode purposive sampling. Jumlah siswa pada penelitian yaitu 3 (tiga) orang siswa kelas VII yang melakukan miskonsepsi matematika rendah, sedang dan tinggi yang memiliki gaya kognitif field independent. Teknik pengumpulan data yang digunakan berupa angket, tes tertulis dan wawancara. Hasil penelitian menunjukkan bahwa siswa yang memiliki gaya kognitif field independent dengan miskonsepsi matematika rendah memiliki kemampuan matematika tinggi. Siswa mampu menyatakan ulang konsep, mampu merumuskan konsep dalam berbagai bentuk representasi matematis, mampu menentukan rumus untuk menjawab soal dan mampu mengaplikasikan rumus yang digunakan. Siswa yang memiliki gaya kognitif field independent dengan miskonsepsi matematika sedang memiliki kemampuan matematika sedang. Siswa tidak mampu menyatakan ulang konsep dikarenakan tidak paham konsep bangun datar persegi dan belah ketupat. Siswa juga tidak mampu merumuskan konsep dalam bentuk representasi gambar. Namun, Siswa mampu menentukan rumus untuk menjawab soal, tetapi tidak mampu mengaplikasikan rumus yang digunakan. Siswa yang memiliki gaya kognitif field independent dengan miskonsepsi matematika tinggi tidak mampu menjawab semua indikator dengan benar. Siswa ini termasuk kategori siswa yang memiliki kemampuan matematika rendah.

Kata Kunci: gaya kognitif field independent, miskonsepsi matematika.

\section{PENDAHULUAN}

Miskonsepsi adalah gagasan yang tidak sesuai dengan definisi yang disepakati oleh para ilmuan dalam suatu bidang. Miskonsepsi juga dapat bermakna pengertian yang tidak sesuai terhadap konsep, penggunaan konsep yang salah, pengelompokan contoh-contoh yang salah, kekacauan konsep-konsep dan hubungan dari urutan konsep-konsep yang tidak benar (Irawan et al., 2012). Dari pendapat tersebut, miskonsepsi matematika adalah penggunaan konsep yang salah dalam pembelajaran matematika. Miskonsepsi matematis dapat dijumpai ketika siswa menyelesaikan masalah matematika. Telah banyak hasil penelitian yang menunjukan bahwa banyak ditemukan siswa-siswa yang salah atau keliru dalam menggunakan konsep matematika dalam menyelesaikan soal.

Hasil penelitian yang dilakukan oleh (Dayanti et al., 2019) menunjukan bahwa 90\% siswa keliru dalam memahami konsep dan keliru dalam menentukan contoh dan bukan contoh. Secara keseluruhan siswa tahu konsep tetapi sangat disayangkan siswa belum mampu menjawab soal dengan benar. Hal ini terjadi karena adanya kesalahan pada penguasan konsep siswa. Hal yang sama juga ditunjukkan oleh hasil wawancara peneliti dengan salah satu guru matematika di SMPN 1 Lunyuk bahwa rata rata siswa belum menguasai konsep-konsep dasar dalam pembelajaran matematika seperti konsep operasi hitung penjumlahan, pengurangan, perkalian dan pembagian. Jika operasi hitung belum dikuasai, maka siswa kesulitan dalam mengaplikasikan berbagai macam rumus matematika. Hal inilah yang membuat siswa masih banyak melakukan miskonsepsi dalam pembelajaran matematika.

Miskonsepsi dapat dipandang sebagai suatu konsepsi atau struktur kognitif yang melekat kuat dan stabil dibenak siswa yang sebenarnya menyimpang dari konsep yang dicetuskan oleh para ahli. Sehingga miskonsepsi sangat berkaitan dengan gaya kognitif yang dimiliki seseorang (Widhiyawati et al., 2020). Setiap individu memiliki karakteristik khas yang tidak dimiliki oleh individu lain. Setiap orang memiliki cara-cara sendiri yang disukainya 
dalam menyusun apa yang dilihat, diingat dan dipikirkannya. Perbedaan perbedaan antar pribadi yang menetap dalam menyusun, mengorganisasi dan mengolah informasi. Pengalaman pengalaman ini dikenal sebagai gaya kognitif (Slameto, 2013, p.160). Selanjutnya, (Desmita, 2017, p.145) menjelaskan bahwa gaya kognitif adalah suatu kekhasan individu dalam menggunakan fungsi kognitifnya seperti berfikir, mengingat, memecahkan masalah, membuat keputusan, mengorganisasi dan memproses informasi yang bersifat konsisten dan berlangsung lama. Artinya gaya kognitif berkaitan dengan bagaimana mereka belajar melalui cara-cara sendiri yang menjadi ciri khas pada masing-masing individu

Ditinjau dari aspek psikologis gaya kognitif terdiri dari dua jenis, yaitu field dependent dan field independent. Seseorang yang memiliki gaya kognitif field dependent dalam menerima suatu informasi lebih secara umum dan mengalami kesulitan dalam menganalisis. Sedangkan seseorang yang memiliki gaya kognitif field independent cenderung lebih analitis dalam menerima informasi (Asmorosari, 2017). Berbagai kecenderungankecenderungan seseorang dalam belajar dapat diidentifikasi dan kemudian dikelompokkan apakah siswa tersebut memiliki gaya kognitif field independent atau field dependent.

(Wooldridge \& Bartolf, 2006) menjelaskan siswa yang bergaya kognitif field dependent bergantung pada struktur lingkungannya, proses belajar bergantung pada pengalaman, mempunyai perhatian singkat yang mudah berubah, suka mempelajari lingkungan, memillih situasi pembelajaran sesuai perasaan dan pengalaman, berorientasi sosial dan kurang berorientasi pada prestasi, dan kurang berkompetisi. Sementara itu, (Witkin et al., 1977) mengidentifikasi ciri-ciri gaya kognitif field dependent sebagai berikut: cenderung untuk berpikir global, cenderung untuk menerima struktur yang sudah ada, memiliki orientasi rasional, cenderung memiliki profesi yang menekankan keterampilan sosial, cenderung mengikuti tujuan yang sudah ada, cenderung bekerja dengan motivasi eksternal serta lebih tertarik pada penguatan eksternal.Dengan demikian dapat disimpulkan bahwa siswa yang bergaya kognitif field dependent lebih mengutamakan pengaruh lingkungan. Siswa dalam berpikir cenderung global (keseluruhan), sehingga meraka mudah mengikuti dan tidak membutuhkan pemikiran secara analitis dan sistematis. Dalam belajar, mereka mempunyai minat yang tinggi terhadap ilmu-ilmu sosial.

Sedangkan gaya kognitif field independent adalah gaya kognitif yang dimiliki seseorang dengan karakteristik mampu menganalisis objek secara terpisah dari lingkungannya, mampu mengorganisasi objek-objek, memiliki orientasi impersonal, memilih profesi yang bersifat individual, dan mengutamakan motivasi dari dalam diri sendiri (Witkin et al., 1977). Dalam proses pembelajaran seseorang dengan karakteristik gaya kognitif field independent akan cenderung mampu mencari informasi lebih banyak diluar konten yang telah ada mampu membedakan suatu objek dari objek sekitarnya dengan lebih mudah dan cenderung lebih analitik dan motivasinya bergantung pada motivasi dari diri sendiri (Nugraha \& Awalliyah, 2016). Hal tersebut menunjukkan bahwa seseorang yang memiliki gaya kognitif field independent lebih cenderung tidak terpengaruh oleh faktor lingkungan dan mereka lebih mengutamakan kemampuan mengolah informasi secara mandiri. Gaya kognitif field independent adalah gaya kognitif yang dimiliki oleh siswa yang cenderung belajar secara mandiri dengan menyatakan suatu masalah secara analitis dan matematis. artinya suatu masalah diuraikan menjadi bagian-bagian kecil dan menemukan hubungan antar bagian-bagian tersebut.

Miskonsepsi matematika yang terjadi pada siswa harus diminimalisir atau dihilangkan dan harus menjadi perhatian khusus bagi guru serta siswa itu sendiri, karena dapat berakibat terganggunya proses belajar dan tercapainya tujuan pembelajaran matematika itu sendiri. Apabila tidak segera diatasi siswa akan tetap mempertahankan konsep yang salah, dan itu akan membuat guru mengalami kesulitan dalam melaksanakan proses pembelajaran untuk mengubah atau membenarkan konsep yang salah tersebut. Oleh karena itu, diperlukan informasi mengenai miskonsepsi untuk menghindari terjadinya miskonsepsi yang berkelanjutan.

\section{METODE}

Pendekatan yang digunakan dalam penelitian ini adalah pendekatan kualitatif deskriptif. Tujuan dari penelitian ini adalah untuk mendeskripsikan bagaimana miskonsepsi matematika siswa ditinjau dari gaya kognitif field independent. Penelitian ini dilakukan di SMPN 1 Lunyuk pada kelas VII, sedangkan waktu penelitian dilaksanakan pada bulan Februari sampai dengan Maret 2021, dengan materi bangun datar segi empat meliputi bangun datar persegi, persegi panjang dan belah ketupat. Jumlah subjek dalam penelitian ini sebanyak 3 (tiga) orang siswa yang memiliki gaya kognitif field independent dengan miskonsepsi matematika rendah, sedang dan tinggi. Penentuan subjek pada penelitian ini menggunakan metode purposive sampling yang merupakan teknik untuk 
menentukan sampel dengan pertimbangan tertentu (Sugiyono, 2012, p.126). Sedangkan objek pada penelitian adalah miskonsepsi siswa dalam menyelesaikan masalah matematika yang diberikan.

Teknik pengumpulan data pada penelitian ini meliputi tes gaya kognitif (Tes GEFT), tes terulis dan wawancara. Sedangkan teknik analisis data yang digunakan dalam penelitian ini diadopsi dari teori menurut (Miles \& Huberman, 1992, p.16) yaitu data reduction (reduksi data), data display (penyajian data), dan calculasion drawing/verification (penarikan kesimpulan). Pada tahap reduksi data, peneliti menyeleksi subjek penelitian dengan mengoreksi hasil instrumen tes gaya kognitif siswa dan mengoreksi hasil tes miskonsepsi matematika. Siswa yang memiliki kecondongan gaya kognitif field independent dan melakukan miskonsepsi rendah, sedang dan tinggi dijadikan subjek penelitian.

Selanjutnya, data hasil miskonsepsi siswa disajikan dalam bentuk gambar. Data dideskripsikan berdasarkan siswa yang melakukan miskonsepsi rendah, sedang dan tinggi serta termasuk dalam kategori siswa dengan kecondongan gaya kognitif field independent. Penentuan gaya kognitif dilakukan dengan memberikan tes GEFT (Group Embed Figure Test) yang terdiri dari 25 item berupa gambar kompleks yang dibagi menjadi tiga bagian pengerjaan selama 20 menit. Bagian pertama berisi tujuh item untuk latihan, bagian kedua dan ketiga masing-masing berisi sembilan item untuk tes dan penskoran. Skor total diperoleh dari sejumlah gambar yang berhasil atau benar dalam pencarian gambar kompleks pada bagian kedua dan ketiga pengerjaan tes. Dengan mengacu pada tes GEFT serta pedoman penskoran gaya kognitif field dependent (FD) dan field independent (FI) yang diadopsi dari penelitian yang dilakukan oleh (Mirlanda \& Pujiastuti, 2018), peneliti dapat menentukan kategori gaya kognitif Field Independent siswa yang dijadikan subjek dalam penelitian seperti pada Tabel 1.

Tabel 1. Pedoman Penskoran Tes GEFT

\begin{tabular}{ccc}
\hline Kategori & Female score & Male score \\
\hline FD & $0-11$ & $0-12$ \\
FI & $12-18$ & $13-18$ \\
\hline
\end{tabular}

Adapun penentuan miskonsepsi matematika siswa menggunakan pedoman penskoran yang diadopsi dari penelitian yang dilakukan oleh (Malikha \& Amir, 2018) seperti yang ditunjukkan pada Tabel 2.

Tabel 2. Pedoman Penskoran Miskonsepsi

\begin{tabular}{ccc}
\hline No & Skor & Kategori \\
\hline 1 & $80 \leq \mathrm{x} \leq 100$ & Tinggi \\
2 & $60 \leq \mathrm{x}<80$ & Sedang \\
3 & $0 \leq \mathrm{x}<60$ & Rendah \\
\hline
\end{tabular}

\section{HASIL DAN PEMBAHASAN}

Hasil tes GEFT yang diberikan untuk menentukan gaya kognitif siswa ditunjukkan pada Tabel 3 berikut

Tabel 3. Hasil Tes GEFT

\begin{tabular}{cccc}
\hline No & Kode Siswa (Jenis Kelamin) & Skor & Kategori \\
\hline 1 & EI (lk) & 15 & FI \\
2 & SU (pr) & 12 & FI \\
3 & RA (lk) & 13 & FI \\
4 & MJ (pr) & 13 & FI \\
5 & RA (lk) & 13 & FIh \\
6 & BH (lk) & 12 & FI \\
7 & MS (lk) & 11 & FD \\
8 & JZ (pr) & 8 & FD \\
9 & IA (pr) & 10 & FD \\
10 & EH (lk) & 11 & FD \\
\hline
\end{tabular}

Berdasarkan Tabel 3, diperoleh hasil bahwa siswa dengan gaya kognitif field independent sebanyak 6 siswa dan siswa dengan gaya kognitif field dependent sebanyak 4 siswa. 6 subjek yang memiliki gaya kognitif field 
independent diberikan tes tertulis untuk menentukan tingkat miskonsepsi matematika siswa. Adapun data hasil tes tertulis ditunjukkan oleh Tabel 4 dibawah ini.

Tabel 4. Hasil Tes Tertulis

\begin{tabular}{cccc}
\hline No & Kode Siswa & Jumlah skor & Kategori \\
\hline 1 & EI & 35 & Rendah \\
2 & SU & 50 & Rendah \\
3 & RA & 45 & Rendah \\
4 & MJ & 60 & Sedang \\
5 & RA & 65 & Sedang \\
6 & BH & 85 & Tinggi \\
\hline
\end{tabular}

Berdasarkan Tabel 4, diperoleh bahwa 3 subjek termasuk kategori miskonsepsi matematika rendah, 2 subjek termasuk kategori miskonsepsi matematika sedang dan 1 subjek termasuk kategori miskonsepsi matematika tinggi. Pada penelitian ini diambil 3 (tiga) orang siswa yang meliputi : a) Field independent dengan miskonsepsi matematika rendah (subjek 01), b) Field independent dengan miskonsepsi matematika sedang (subjek 02), c) Field independent dengan miskonsepsi matematika tinggi (subjek 03).

Subjek pada penelitian diberikan 3 butir soal, dimana setiap nomor soal memiliki satu atau beberapa indikator miskonsepsi matematika. Soal nomor satu digunakan untuk melihat miskonsepsi matematika siswa pada indikator tidak dapat menyatakan ulang konsep. Soal nomor dua digunakan untuk melihat miskonsepsi matematika siswa pada tiga indikator yaitu: indikator tidak mampu merumuskan konsep dalam berbagai bentuk representasi matematis dengan benar, indikator tidak dapat menentukan rumus untuk menjawab suatu masalah dan indikator tidak dapat mengaplikasan rumus atau algoritma pemecahan masalah. Sedangkan pada soal nomor tiga digunakan untuk melihat miskonsepsi matematika hanya pada indikator tidak dapat mengaplikasikan rumus atau algoritma pemecahan masalah.

\section{Siswa yang Memiliki Gaya Kognitif Field Independent dengan Miskonsepsi Matematika Rendah (Subjek 01)} gambar 1.

Hasil tes tertulis siswa dengan miskonsepsi matematika rendah untuk soal nomor satu ditunjukkan pada

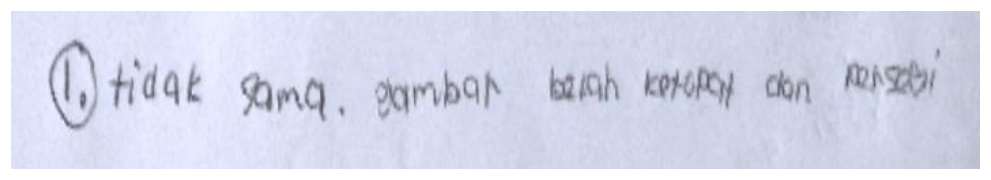

Gambar 1. Jawaban Subjek 01 soal nomor satu

Pada indikator tidak mampu menyatakan ulang konsep, siswa tidak dapat menyatakan ulang konsep dari kedua bangun datar persegi dan belah ketupat dengan benar dan detail. Siswa tidak menuliskan alasan kedua bangun tersebut tidak sama dengan tidak menuliskan sifat atau ciri ciri dari bangun datar persegi dan belah ketupat. Akan tetapi siswa mampu menuliskan bahwa kedua bangun datar tidak sama dan dapat menyebutkan nama dari kedua bangun datar tersebut.

Berdasarkan hasil wawancara menunjukkan bahwa siswa dapat menyebutkan ciri ciri dari bangun datar persegi dengan tepat. Namun, siswa tidak paham sepenuhnya dengan konsep bangun datar belah ketupat sehingga tidak dapat menyebutkan ciri ciri dari bangun datar belah ketupat. Hal ini disebabkan karena siswa tidak sepenuhnya paham dengan konsep bangun datar belah ketupat. Siswa juga tidak fokus menyelesaikan soal nomor satu dengan tuntas karena beralih mengerjakan nomor berikutnya. Selain itu, siswa tidak mengecek kembali jawaban sebelum dikumpulkan. Hal ini sejalan dengan pendapat (Wasida \& Hartono, 2018) bahwa pengecekan kembali hasil pekerjaan sering tidak dilakukan oleh siswa seperti yang terjadi pada penelitian sebelumnya.

Selanjutnya, hasil pengerjaan untuk soal nomor dua seperti yang ditunjukkan pada Gambar 2. 


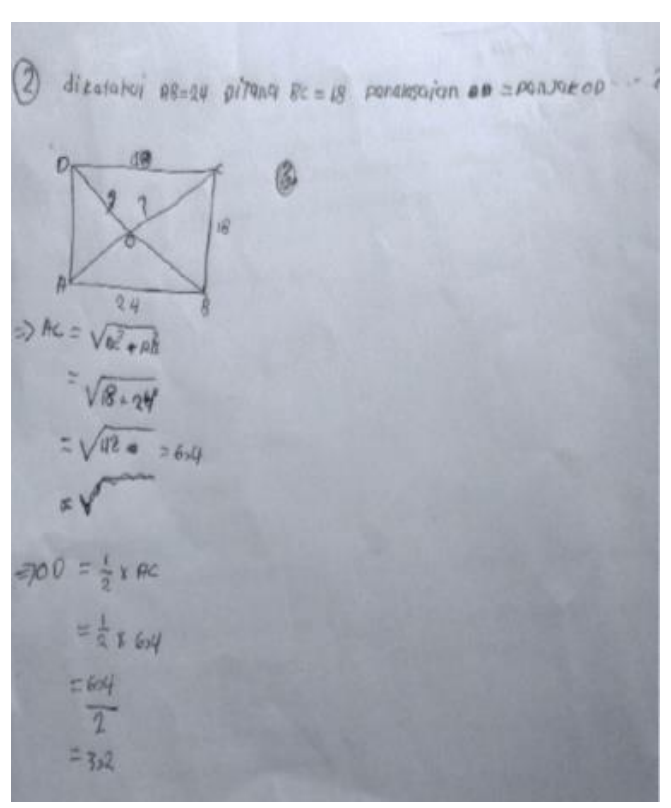

Gambar 2. Jawaban Subjek 01 soal nomor dua

Pada soal nomor dua, siswa hanya dapat menjawab dua indikator soal yaitu : merepresentasikan soal dalam bentuk gambar dengan membuat gambar persegi panjang $\mathrm{ABCD}$ dengan benar dan siswa memberikan keterangan nilai dari masing masing rusuk atau sisi dengan detail dan jelas, dan menentukan rumus yang digunakan untuk menyelesaikan soal dengan benar yaitu menggunakan rumus theorema phytagoras untuk menjawab soal. Akan tetapi siswa tidak dapat mengoperasikan rumus dengan benar yang ditunjukkan dengan adanya kesalahan pada tahap kedua dan ketiga. Siswa tidak mengkuadratkan terlebih dahulu kedua nilai yang berada didalam tanda akar sebelum di jumlahkan. Sehingga mendapatkan nilai yang salah pada tahap akhir penyelesaian.

Pada indikator tidak mampu merumuskan konsep dalam berbagai bentuk representasi matematis dengan benar, siswa dapat menggambar persegi panjang dengan benar dan detail berdasarkan informasi yang diketahui pada soal. Hal ini sesuai dengan salah satu karakteristik siswa dengan gaya kognitif field independent yaitu siswa mampu menciptakan struktur meskipun struktur tersebut tidak melekat didalam informasi yang ada (Altun \& Cakan, 2006). Selanjutnya, pada indikator tidak mampu menentukan rumus untuk menyelesaikan masalah, siswa dapat menentukan rumus yang digunakan dengan menggunakan rumus theorema phytagoras untuk mengetahui salah satu diagonal persegi panjang dengan benar.

Sedangkan pada indikator tidak mampu mengaplikasikan rumus atau algoritma pemecahan masalah soal nomor dua, siswa tidak mampu mengolah informasi yang ada pada soal dengan benar. Siswa juga tidak teliti dalam mengoperasikan nilai yang sudah disubstitusikan kedalam rumus sehingga memperoleh hasil akhir yang tidak benar. Berdasarkan hasil wawancara, didapatkan hasil bahwa siswa keliru dalam megoperasikan angka yang sudah disubstitusikan kedalam rumus disebabkan karena siswa lupa dan tidak memeriksa kembali lembar jawaban sebelum dikumpulkan. Penelitian (Harahap et al., 2019) juga menunjukkan bahwa ketidaktelitian dapat menyebabkan kesalahan dalam menyelesaikan soal.

Pada soal nomor tiga, siswa dapat menjawab indikator yang diinginkan oleh soal dengan menentukan rumus yang digunakan dan merepresentasikan rumus yang digunakan dengan benar. Proses penyelesaian yang dilakukan juga sudah benar dan sistematis. Berdasarkan hasil wawancara, siswa tidak mendapat kesulitan dalam memecahkan soal yang diberikan sehingga siswa dapat menjawab soal nomor tiga dengan tepat sesuai dengan indikator yang diinginkan soal. Ini ditunjukkan dengan respon siswa pada saat wawancara sama dengan jawaban soal nomor tiga.

Pada indikator tidak dapat mengaplikasikan rumus atau algoritma pemecahan masalah soal nomor tiga, siswa dapat mengaplikasikan rumus yang digunakan dengan benar, detail dan sistematis. Hal ini menunjukkan bahwa siswa dapat memproses informasi dan mampu memecahkan masalah atau soal dengan penyelesaian yang seharusnya. Hal ini sejalan dengan yang dikemukakan oleh (Asmorosari, 2017) yang menyatakan bahwa Salah satu indikator gaya kognitif field independent adalah siswa mampu menjawab soal dengan benar. 


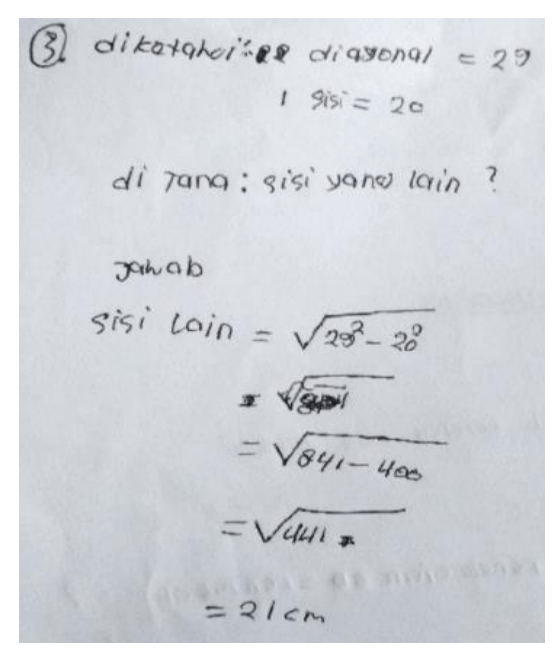

Gambar 3. Jawaban Subjek 01 soal nomor tiga

\section{Siswa yang Memiliki Gaya Kognitif Field Independent dengan Miskonsepsi Matematika Sedang (Subjek 02)} Gambar 4.

Hasil tes tertulis siswa dengan miskonsepsi matematika sedang untuk soal nomor satu ditunjukkan oleh

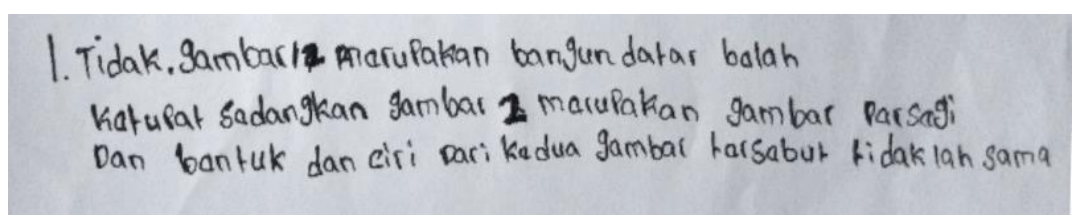

Gambar 4. Jawaban Subjek 02 Soal Nomor Satu

Berdasarkan Gambar 4, siswa dapat menjawab soal dengan dapat menentukan nama bangun dari masing masing gambar dengan benar. Namun, siswa tidak menuliskan alasan dengan detail karena tidaak menjelaskan ciri ciri atau sifat dari kedua bangun datar tersebut. Berdasarkan hasil wawancara dengan siswa, didapatkan hasil bahwa siswa belum sepenuhnya memahami konsep persegi dan belah ketupat itu sendiri, sehingga siswa tidak dapat menjawab beberapa ciri ciri dari kedua bangun tersebut dan tidak dapat menjawab apakah persegi merupakan belah ketupat atau tidak.

Pada indikator tidak mampu menyatakan ulang konsep, siswa tidak dapat menyatakan ulag konsep dengan benar dan detail. Siswa hanya dapat membedakan kedua bangun dengan menyebutkan nama dari masing masing bangun datar tersebut, tetapi siswa tidak menuliskan alasan dari jawaban yang ditulis. Akan tetapi berdasarkan hasil wawancara, diketahui bahwa siswa tidak paham konsep kedua bangun datar tersebut karena siswa tidak mampu memahami dan mengingat kembali materi yang sudah diajarkan. Sehingga siswa tidak dapat menyebutkan ciri ciri atau sifat dari masing masing bangun datar tersebut. Hal inilah yang menjadi alasan siswa tidak menuliskan alasan dari jawaban yang diberikan. Hal demikian juga terjadi pada penelitian (Dedeng et al., 2020) yaitu siswa yang mengalami miskonsepsi merupakan siswa yang mampu memilih jawaban yang benar, namun tidak bisa memberikan alasan yang benar.

Pada soal nomor dua, siswa hanya bisa menjawab satu indikator soal saja yaitu dapat menentukan rumus yang digunakan untuk menyelesaikan soal. Akan tetapi siswa tidak dapat : 1) Merepresentasikan soal dalam bentuk gambar persegi panjang $A B C D$ yang sudah diberi nilai pada sisi sisi yang diketahui di soal. 2) Mengaplikasikan rumus dengan benar. Siswa tidak dapat mengaplikasikan rumus dengan benar pada tahap mencari panjang $\mathrm{AC}$ dan panjang $\mathrm{OD}$ Sehingga memperoleh hasil yang kurang tepat.

Berdasarkan hasil wawancara dengan siswa didapati penyebab kesalahan hasil yaitu : siswa keliru dalam membuat pemisalan dengan gambar. Siswa memisalkan soal dengan gambar persegi sementara soal pada nomor dua membahas persegi panjang. Selain itu, siswa keliru dalam menghitung nilai akar pada saat penyelesaian tahap akhir dalam mencari nilai AC.

Pada indikator tidak mampu merumuskan konsep dalam berbagai bentuk representasi matematis dengan benar, siswa tidak dapat menggambar persegi panjang dengan benar dan detail. Setelah melakukan wawancara 
diketahui siswa menganggap bahwa pemisalan yang digambarkan pada lembar jawabannya adalah gambar persegi panjang, namun yang digambarkan adalah bangun datar persegi. Hal ini menunjukkan bahwa siswa paham soal nomor dua tentang bangun datar persegi panjang, akan tetapi siswa kurang teliti dalam memproses informasi yang ada pada soal.

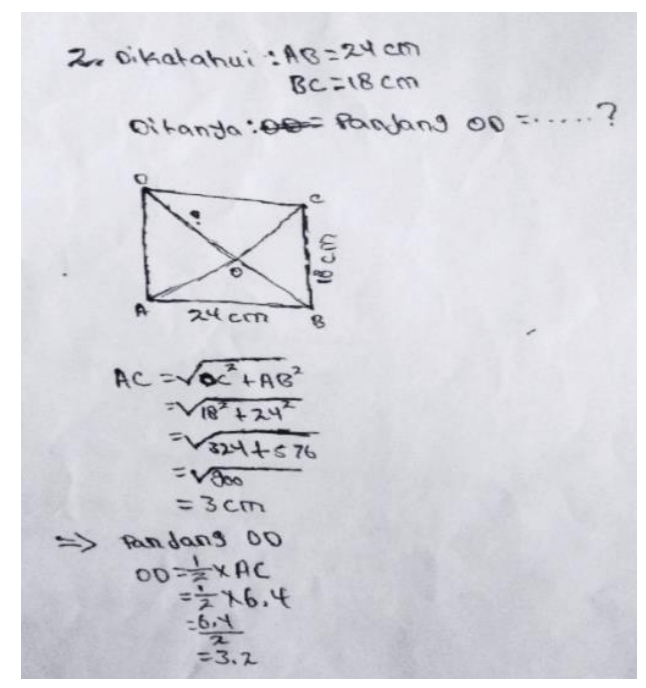

Gambar 5. Jawaban Subjek 02 Soal Nomor Dua

Pada indikator tidak mampu menentukan rumus untuk menjawab suatu masalah, siswa dapat menentukan rumus yang digunakan untuk menyelesaikan soal dengan menuliskan rumus theorema phytagoras untuk mengetahui salah satu diagonal persegi panjang. Berdasarkan hasil wawancara, siswa tidak dapat menjelaskan alasan pemilihan rumus yang digunakan. Hal ini menunjukkan bahwa siswa tidak dapat memahami dan mengingat kembali materi yang diajarkan pada saat penyampaian materi. Berdasarkan hasil wawancara, diketahui bahwa siswa tidak teliti dalam mengoperasikan rumus dan siswa tidak paham tahapan tahapan dalam penyelesaian soal. Hal serupa juga terjadi dalam hasil penelitian (Susandi \& Widyawati, 2017) bahwa alah satu siswa yang mempunyai gaya kognitif field independent tidak mampu menyelesaikan soal sesuai tahapan tahapan dalam pengerjaan soal.

Pada soal nomor tiga, siswa dapat menjawab soal sesuai indikator yaitu dapat menentukan rumus untuk menjawab suatu masalah. Siswa dapat menentukan rumus untuk mencari sisi persegi panjang yang tidak diketahui pada soal. Akan tetapi siswa keliru dalam merepresentasikan atau mengoperasikan rumus yang digunakan sehingga tidak memperoleh hasil yang benar.

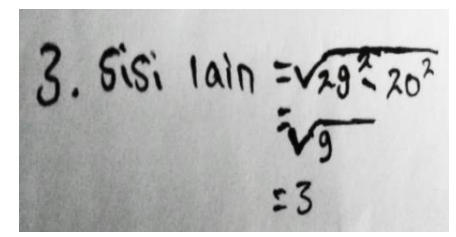

Gambar 6. Jawaban Subjek 02 Soal Nomor Tiga

Dari hasil wawancara didapatkan hasil bahwa siswa salah dalam mengoperasikan atau merepresentasikan rumus yang digunakan dengan tidak mengoperasikan pemangkatan terlebih dahulu sehingga tidak memperoleh hasil yang benar. Pada indikator tidak mampu mengaplikasikan rumus atau algoritma pemecahan masalah soal nomor dua dan tiga, siswa tidak dapat mengaplikasikan rumus dengan benar, detail dan sistematis. hasil wawancara menunjukkan bahwa siswa tidak teliti dalam mengoperasikan angka atau nilai setelah disubstitusikan kedalam rumus. Hal ini menunjukkan bahwa siswa tidak dapat mengolah atau memproses informasi yang ada pada soal dengan benar, detail dan sistematis.

\section{Siswa yang Memiliki Gaya Kognitif Field Independent dengan Miskonsepsi Matematika Tinggi (Subjek 03)}

Pada soal nomor satu, siswa tidak dapat menjawab indikator menyatakan ulang konsep. Siswa hanya menuliskan jawaban singkat dan kurang tepat. Tetapi siswa tidak menulis alasan terhadap jawaban yang diberikan, seperti yang ditunjukkan pada gambar 7 . 


\section{Tidak Saina}

Gambar 7. Jawaban Subjek 03 Soal Nomor Satu

Pada indikator tidak mampu menyatakan ulang konsep, siswa tidak dapat menyatakan ulang konsep persegi dan belah ketupat dengan tidak menuliskan nama dari masing masing bangun dan tidak menuliskan alasan dari jawaban yang ditulis. Dari hasil wawancara dengan siswa, didapatkan hasil bahwa siswa belum paham sepenuhnya konsep dari masing masing bangun datar persegi dan belah ketupat. ini dilihat dari ketika berlangsungnya proses pemberian materi siswa tidak fokus dalam menerima materi dan ketika proses wawancara siswa terlihat bingung ketika menjawab pertanyaan. Ssiswa dikatakan tidak paham konsep apabila siswa tidak mampu mengemukakan atau menjelaskan kembali suatu konsep yang telah dipelajari sebelumnya. Hal ini sejalan dengan penelitian (Ningrum \& Budiarto, 2016) yaitu siswa tidak dapat memahami dan mengingat kembali materi yang sudah di ajarkan pada saat proses penyampaian materi.

Pada soal nomor dua, siswa tidak dapat menjawab semua indikator soal seperti: tidak dapat merepresentasikan soal dalam bentuk gambar, tidak dapat menentukan rumus yang digunakan untuk menyelesaikan soal dengan tidak memberi pangkat pada nilai sisi yang berada dalam tanda akar, dan tidak dapat mengaplikasikan rumus dengan benar dan sistematis. Oleh karena itu, siswa mendapatkan hasil yang tidak benar, seperti pada gambar 8 .

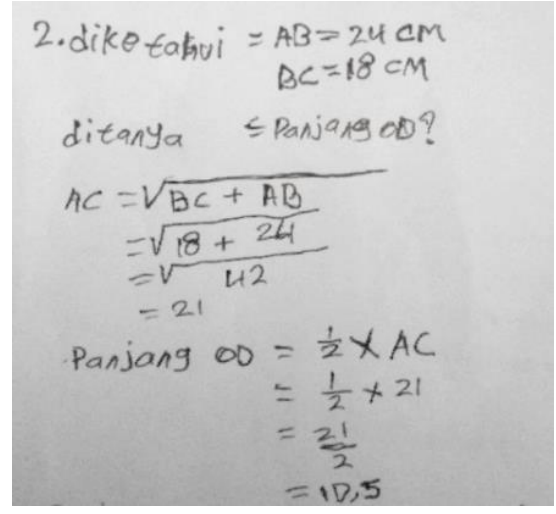

Gambar 8. Jawaban Subjek 03 Soal Nomor Dua

Berdasarkan hasil wawancara dengan siswa, didapati hasil bahwa siswa tidak tidak dapat memberikan alasan pemilihan rumus theorema phytagoras yang digunakan. Ini menunjukkan bahwa siswa tidak paham konsep persegi panjang dan tahap pengerjaan soal. Selain itu, siswa tidak paham definisi nilai akar sehingga tidak dapat mengoperasikan nilai yang berada dalam akar pada tahap kedua.

Pada indikator tidak mampu merumuskan konsep dalam berbagai bentuk representasi matematis dengan benar, siswa juga tidak mampu menggambar persegi panjang sesuai dengan informasi yang ada pada soal. Berdasarkan hasil wawancara diketahui bahwa siswa tidak paham tahapan dalam pengerjaan soal. Hal ini menunjukkan bahwa siswa tidak dapat memahami, mengingat, memproses dan menggambarkan informasi yang ada pada soal. Selain itu, pada saat proses penyampaian materi, siswa jarang memperhatikan penjelasan dan tidak pernah bertanya terkait materi yang belum dipahami. Hal ini dikemukanan oleh (Febriyanti \& Seruni, 2015) salah satu hal yang dapat menunjang kemampuan siswa dalam memahami masalah adalah adanya interaksi atau komunikasi dengan guru.

Pada indikator tidak dapat menentukan rumus yang digunakan untuk menyelesaikan soal, siswa tidak dapat menentukan rumus untuk menjawab soal dengan tidak menuliskan rumus theorema phytagoras untuk mencari nilai salah satu diagonal persegi panjang. Siswa menggunakan rumus yang hampir sama dengan rumus theorema phytagoras, namun siswa tidak mengkuadratkan sisi tegak dan sisi alas. Hal ini disebabkan karena siswa tidak paham konsep mencari nilai sisi miring. Siswa mengalami miskonsepsi pemahaman tentang rumus theorema phytagoras dimana siswa menyebutkan sisi miring merupakan hasil akar dari jumlah sisi tegak dan sisi alas tanpa dikuadratkan (Ramadhan et al., 2017). 
Selanjutnya, pada soal nomor tiga, siswa tidak dapat menjawab soal sesuai indikator yang diinginkan soal. Hasil pengerjaannya seperti pada gambar berikut.

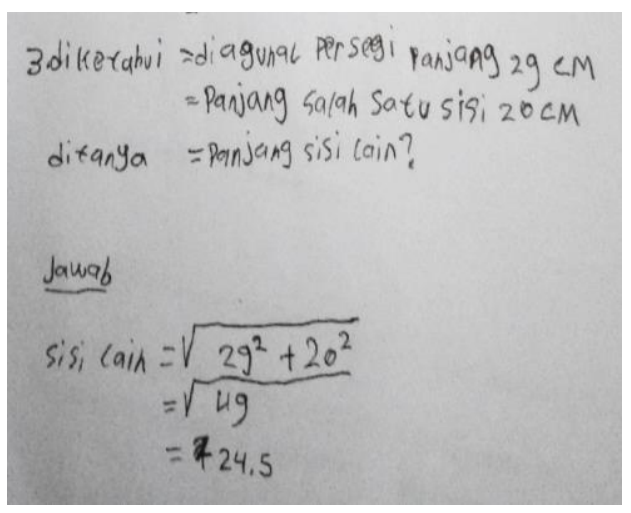

Gambar 9. Jawaban Subjek 03 Soal Nomor Tiga

Siswa tidak dapat menjawab soal sesuai indikator yang diinginkan seperti: siswa menggunakan rumus yang salah dalam menyelesaikan soal dengan menggunakan tanda operasi penjumlahan untuk mengoperasikan nilai yang berada dalam tanda akar, dalam mengaplikasikan rumus yang digunakan, siswa tidak mengoperasikan nilai yang dipangkatkan terlebih dahulu sebelum dijumlahkan, dan siswa salah dalam menentukan nilai akar. Berdasarkan wawancara dengan siswa, diperoleh hasil bahwa: siswa tidak mengetahui alasan memilih rumus yang digunakan, siswa tidak menggunakan tanda operasi pengurangan sehingga memperoleh hasil yang tidak benar dalam menggunakan rumus, dan siswa tidak paham konsep mencari nilai akar.

Pada indikator tidak dapat megaplikasikan rumus atau algoritma pemecahan masalah, siswa tidak dapat mengoperasikan rumus yang digunakan pada soal nomor dua dan tiga dengan benar, detail dan sistematis. Hal tersebut dikarenakan siswa tidak paham konsep dasar yaitu cara memperoleh nilai akar yang mengakibatkan kesalahan hasil akhir yang diperoleh. Hal ini menunjukkan bahwa siswa tidak mampu memahami dan mengingat kembali konsep konsep dasar matematika. Kemampuan pemahaman konsep sebelumnya dapat mempengaruhi hasil belajar selanjutnya (Ansari, 2016, p.38)

\section{SIMPULAN}

Berdasarkan hasil penelitian dan pembahasan, dapat disimpulkan dari masing masing indikator miskonsepsi matematika berdasarkan gaya kognitif field independent. Siswa yang memiliki gaya kognitif field independent dengan miskonsepsi matematika rendah memiliki kemampuan matematika tinggi. Siswa mampu menyatakan ulang konsep bangun datar dengan benar, dapat merepresentasikan soal dalam bentuk gambar dengan benar, detail dan rapi. Siswa juga dapat menentukan rumus untuk menjawab soal dengan benar serta siswa mampu mengaplikasikan rumus yang digunakan dengan benar, detail dan sistematis. Hal ini menunjukkan bahwa siswa mampu memahami, mengingat dan memproses informasi yang ada. Namun, pada soal nomor dua siswa tidak dapat mengaplikasikan rumus dengan benar, detail dan sistematis dikarenakan kurang teliti dalam mwengoperasikan rumus yang digunakan.

Siswa yang memiliki gaya kognitif field independent dengan miskonsepsi matematika sedang memiliki kemampuan matematika sedang. Siswa tidak mampu menyatakan ulang konsep bangun datar dengan benar disebabkan karena siswa tidak memahami konsep dasar, tidak dapat merepresentasikan soal dalam bentuk gambar dengan benar, detail dan rapi disebabkan karena siswa kurang teliti. Selain itu, siswa dapat mengingat rumus untuk menjawab soal dengan benar, tetapi terdapat kekeliruan perhitungan yang disebabkan siswa kurang teliti selama menjawab soal.

Siswa yang memiliki gaya kognitif field independent dengan miskonsepsi matematika tinggi memiliki kemampuan matematika rendah. Siswa tidak mampu menyatakan ulang konsep bangun datar dengan benar dan tidak dapat memproses informasi dengan merepresentasikan soal dalam bentuk gambar dengan tepat dan detail. Hal ini disebabkan oleh ketidakpahaman siswa mengenai konsep bangun datar persegi dan belah ketupat. Siswa juga tidak dapat menentukan rumus dengan benar yang disebabkan oleh ketidaktahuan siswa mengenai konsep diagonal bangun datar dan segitiga siku-siku. Selain itu, siswa juga tidak mampu mengaplikasikan rumus yang digunakan dengan benar, detail dan sistematis. 


\section{Daftar Pustaka}

Altun, A., \& Cakan, M. (2006). Undergraduate Students' Academic Achievement, Field Dependent/Independent Cognitive Styles and Attitude Toward Computers. Educational Technology and Society, 9(1), 289-297.

Ansari, B. I. (2016). Komunikasi Matematika Strategi Berpikir dan Manajemen Belajar Konsep dan Aplikasi. PeNA.

Asmorosari, D. (2017). Analisis Gaya Kognitif Siswa Dengan Hasil Belajar Ekonomi Peminatan Di SMAN Pontianak. Artikel Penelitian Universitas Tanjung Pura Pontianak.

Dayanti, P., Sugiatno, \& Nursangaji, A. (2019). Miskonsepsi Siswa Dikaji dari Gaya Kognitif dalam Materi Jajargenjang di Sekolah Menengah Pertama. Jurnal Pendidikan Dan Pembelajaran Khatulistiwa, 8(9), 1-9. https://jurnal.untan.ac.id/index.php/jpdpb/article/view/35928/75676583118

Dedeng, E., Fayeldi, T., \& Ferdiani, R. D. (2020). Analisis Miskonsepsi Siswa Kelas VIII Pada Sub Materi Penyelesaian SPLDV Dan Penerapan SPLDV Menggunakan Three Tier-Test. RAINSTEK: Jurnal Terapan Sains $\mathcal{E}$ Teknologi, 2(2), 129-135. https://doi.org/10.21067/jtst.v2i2.4639

Desmita. (2017). Psikologi Perkembangan Peserta Didik. Remaja Rosdakarya.

Febriyanti, C., \& Seruni, S. (2015). Peran Minat dan Interaksi Siswa dengan Guru Dalam Meningkatkan Hasil Belajar Matematika. Formatif: Jurnal Ilmiah Pendidikan MIPA, 4(3), 245-254. https://doi.org/10.30998/formatif.v4i3.161

Harahap, Z. I. S., Muchlis, E. E., \& Maulidiya, D. (2019). Faktor - Faktor Penyebab Kesalahan Siswa Dalam Menyelesaikan Soal Matematika Tentang Luas Permukaan Kubus Dan Balok. Jurnal Penelitian Pembelajaran Matematika Sekolah (JP2MS), 3(3), 342-352. https://doi.org/10.33369/jp2ms.3.3.342-352

Irawan, E., Riyadi, R., \& Triyanto, T. (2012). Analisis Miskonsepsi Mahasiswa STKIP PGRI Pacitan pada Mata Kuliah Pengantar Dasar Matematika Pokok Bahasan Logika Ditinjau dari Gaya Kognitif Mahasiswa. Journal of Mathematics and Mathematics Education, 2(1), 1-18. https://doi.org/10.20961/jmme.v2i1.9942

Malikha, Z., \& Amir, M. F. (2018). Analisis Miskonsepsi Siswa Kelas V-B MIN Buduran Sidoarjo pada Materi Pecahan Ditinjau dari Kemampuan Matematika. Pi: Mathematics Education Journal, 1(2), 75-81. https://doi.org/10.21067/pmej.v1i2.2329

Miles, M. B., \& Huberman, A. M. (1992). Analisis Data Kualitatif: Buku Sumber tentang Metode-Metode Baru. UI Press.

Mirlanda, E. P., \& Pujiastuti, H. (2018). Kemampuan Penalaran Matematis: Analisis Berdasarkan Gaya Kognitif Siswa. Symmetry: Pasundan Journal of Research in Mathematics Learning and Education, 3(2), 56-67. https://doi.org/10.23969/symmetry.v3i2.1252

Ningrum, R. W., \& Budiarto, M. T. (2016). Miskonsepsi Siswa SMP pada Materi Bangun Datar Segiempat dan Alternatif Mengatasinya. Jurnal Ilmiah Pendidikan Matematika, 1(5), 59-66. https://jurnalmahasiswa.unesa.ac.id/index.php/mathedunesa/article/view/25554/23429

Nugraha, M. G., \& Awalliyah, S. (2016). Analisis Gaya Kognitif Field Dependent Dan Field Independent Terhadap Penguasaan Konsep Fisika Siswa Kelas VII. Prosiding Seminar Nasional Fisika (E-Journal) SNF2016, V, 71-76. https://doi.org/10.21009/0305010312

Ramadhan, M., Sunardi, \& Kurniati, D. (2017). Analisis Miskonsepsi Siswa dalam Menyelesaikan Soal Matematika Berstandar Pisa dengan Menggunakan Certainty of Response Index (CRI). Kadikma: Jurnal Matematika Dan Pendidikan Matematika, 8(1), 145-153. https://doi.org/https://doi.org/10.19184/kdma.v8i1.5276

Slameto. (2013). Belajar dan Faktor-Faktor yang Mempengaruhinya. Rineka Cipta.

Sugiyono. (2012). Metode Penelitian Kuantitatif, Kualitatif, dan REDD. Alfabeta.

Susandi, A. D., \& Widyawati, S. (2017). Proses Berpikir dalam Memecahkan Masalah Logika Matematika Ditinjau dari Gaya Kognitif Field Independent dan Field Dependent. Numerical: Jurnal Matematika Dan Pendidikan Matematika, 1(1), 45-52. https://doi.org/10.25217/numerical.v1i1.122

Wasida, M. R., \& Hartono. (2018). Analisis Kesulitan Menyelesaikan Soal Model Ujian Nasional Matematika dan Self-Efficacy Siswa SMA. Jurnal Riset Pendidikan Matematika, 5(1), 82-95. https://doi.org/10.21831/jrpm.v5i1.10060

Widhiyawati, Kurniasih, N., \& Purwaningsih, W. I. (2020). Analisis Miskonsepsi Siswa dalam Menyelesaikan Permasalahan pada Materi Program Linear Ditinjau dari Gaya Kognitif Fiels Independent. Ekuivalen: Jurnal Pendidikan Matematika, 43(1), 25-29. 
Witkin, H. A., Moore, C. A., Goodenough, D., \& Cox, P. W. (1977). Field-Dependent and Field-Independent Cognitive Styles and Their Educational Implications. Review of Educational Research, 47(1), 1-64. https://doi.org/10.3102/00346543047001001

Wooldridge, B., \& Bartolf, M. H. (2006). The Field Dependence/Field Independence Learning Style: Implications for Adult Student Diversity, Outcomes Assesment and Accountability. In Learning Styles and Learning (pp. 237-257). Nova Science Publisher, Inc. 